\title{
Rancangan Strategi Portofolio Optimal PT. ABC dengan Metode Single Index Model
}

\section{Optimal Portfolio Strategy Design PT. ABC with Single Index Model Method}

\author{
Ramadhan Dwi Saputra1 ${ }^{*}$, Irham Alifiandipura1 \\ 1) Sekolah Tinggi Manajemen PPM \\ *Coresponding Email: aeroradista@gmail.com
}

\begin{abstract}
Abstrak
Sebagai perusahaan asuransi sosial Republik Indonesia, PT ABC (Persero) memiliki pasar yang tetap (captive market) berdasarkan ketentuan perundang-undangan yang berlaku. Perusahaan mengelola dana yang berasal dari pemerintah, dan merupakan salah satu dari empat produk asuransi yang ada di perusahaan ke dalam portofolio investasi. Sebagai salah satu revenue generator perusahaan, PT ABC perlu menempatkan dana yang dikelola ke dalam instrumen investasi yang memilki return tinggi untuk memenuhi kebutuhan perusahaan, salah satunya melalui instrumen saham. Pembentukan portofolio saham dilakukan melalui pendekatan portofolio optimal dengan metode single index model. Jenis penelitian deskriptif kuantitatif dengan alat analisis dan olah data dalam penelitian ini menggunakan software Microsoft Excel. Portofolio dibentuk kedalam beberapa skenario dengan mempertimbangkan komposisi portofolio pada salah satu produk perusahaan dan pergerakan harga saham di Indonesia. Data yang digunakan dalam penelitian ini adalah data historis pergerakan saham harian selama lima tahun periode perdagangan tahun 2014-2018 dan data historis portofolio investasi saham produk XYZ tahun 2018. Dari penelitian ini, dihasilkan 2 rancangan strategi pembentukan portofolio perusahaan serta 1 rekomendasi saham-saham yang memiliki ketahanan yang baik selama masa pandemi. Hasil dari perhitungan diharapkan dapat menjadi bahan pertimbangan perusahaan dalam pembentukan portofolio perusahaan ke depan.
\end{abstract}

Kata Kunci: Portofolio Optimal, Single Index Model, Investasi, Saham.

\begin{abstract}
As social insurance company of the Republic of Indonesia, PT ABC (Persero) has a captive market based on the provisions of Undang-undang in Indonesia. The company has managed funds from the government, and is one of the four insurance products in the company, into an investment portfolio. As one of the company's revenue generator, PT ABC needs to put the fund into investment instruments that have higher returns to meet the needs of the company, one of which is through stock investment. The formation of stock portfolio is carried out through an optimum portfolio approach by using single index model method. This is a quantitative descriptive research using analysis tools and data processing by Microsoft Excel software. Portfolios are formed into several scenarios by considering the composition of the current portfolio in one of the company's products and stock price movements in Indonesia. The data used in this study are historical data on daily stock movements for the five years of the 20142018 trading period and historical data on the investment portfolio for XYZ products in 2018. From this research, 2 strategic plans for forming company portfolios and 1 recommendation of stocks are produced that have good resilience during a pandemic. The results of the calculations are expected to be taken into consideration by the company in the formation of future company portfolios.
\end{abstract}

Keywords: Portfolio Optimum, Single Index Model, Investment, Stock.

How to Cite: Saputra, R.D. \& Alifiandipura, I. (2021). Rancangan Strategi Portofolio Optimal PT. ABC dengan Metode Single Index Model. JKBM (Jurnal Konsep Bisnis dan Manajemen). 8 (1): 58-69 


\section{PENDAHULUAN}

PT ABC merupakan salah satu BUMN yang bertugas mengelola dana pertanggungan dan pensiun nasabah. Sebagai perusahaan asuransi sosial, PT ABC memiliki pasar yang tetap berdasarkan ketentuan perundang-undangan (captive market). Kontribusi premi yang diterima perusahaan secara umum bersifat tetap, sehingga perusahaan perlu mengelola dana premi ke dalam berbagai bentuk investasi yang memiliki imbal hasil yang tinggi. Sebagaimana penempatan investasi yang diatur oleh Kementerian Keuangan dan OJK, perusahaan menempatkan dana mereka ke dalam beberapa instrumen investasi. Gambar 1 menunjukkan komposisi alokasi aset investasi PT ABC pada tahun 2018. Berdasarkan grafik tersebut, komposisi alokasi aset perusahaan terbesar berada pada instrumen reksadana sebanyak $37.62 \%$ dan saham sebesar 33.49\%.

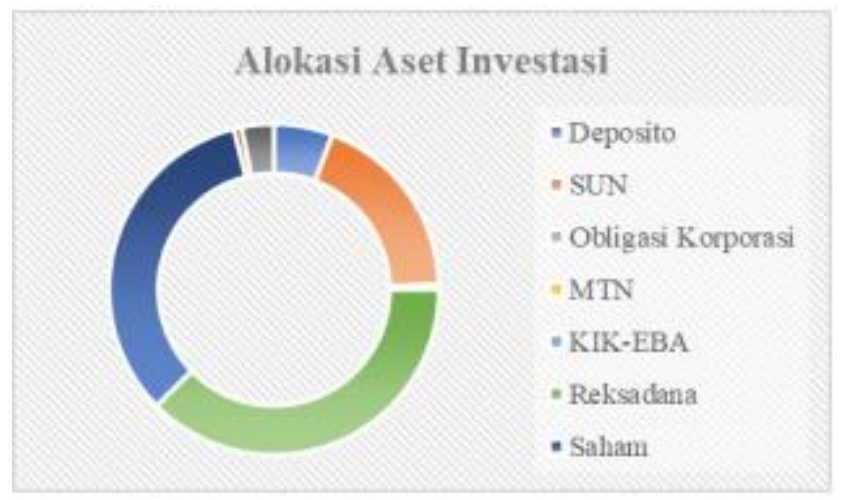

Gambar 1. Alokasi aset investasi PT ABC 2018 Sumber: Laporan Investasi Perusahaan Tahun 2018

Komposisi saham yang dimiliki perusahaan cukup beragam. Dalam program XYZ sendiri terdapat 21 kelas aset saham yang dimiliki perusahaan. Secara umum porsi kepemilikan saham dalam keseluruhan total aset perusahaan mengalami peningkatan. Hal ini dapat disebabkan oleh pertumbuhan nilai saham yang terus meningkat maupun atas penambahan aset baru. Walaupun demikian, perusahaan mengalami penurunan aset yang cukup signifikan pada tahun 2019. Hal ini disebabkan oleh menurunnya nilai saham yang dimiliki perusahaan, namun masih dalam status kepemilikan (unrealized loss). Sebagai salah satu instrumen investasi yang berisiko, diperlukan suatu strategi portfolio investasi dalam menilai keuntungan yang diharapkan dengan tingkat risiko tertentu pada portfolio saham perusahaan.

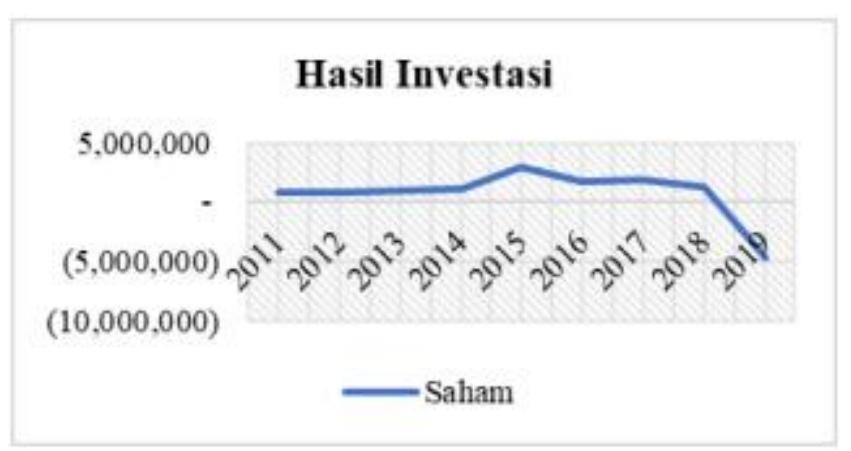

Gambar 2. Hasil investasi saham perusahaan Sumber: Laporan Investasi Perusahaan Tahun 2018

Grafik di atas adalah hasil investasi portofolio saham perusahaan sembilan tahun terakhir (2011-2019) pada salah satu produk yang mengalami penurunan. Selain karena perubahan proporsi yang cukup besar, penurunan imbal hasil instrumen saham memiliki volatilitas fluktuatif yang memiliki risiko kerugian yang cukup besar. Jika dilihat dari konsep strategi alokasi aset secara umum, perusahaan dapat melakukan aksi rebalancing atas kelas aset yang telah dibentuk. Namun, mengingat perusahan adalah salah satu badan usaha milik negara, perusahaan dibatasi oleh Undang-undang Nomor 1 Tahun 2004 tentang perbendaharaan negara terkait pengelolaan unrealized loss pada portofolio investasi yang dianggap dapat merugikan negara. 
Saputra, R.D. \& Alifiandipura, I. (2021). Rancangan Strategi Portofolio Optimal PT. ABC dengan Metode Single Index ...

Aktivitas investasi perusahaan tidak hanya dapat didasarkan pada tingkat keuntungan yang diperoleh saja, namun perlu mempertimbangkan tingkat risiko dari setiap kelas aset yang hendak dibentuk. Diversifikasi pada pembentukan portofolio diperlukan untuk meminimalisir tingkat risiko, serta memaksimalkan tingkat keuntungan yang diterima secara efisien dan optimal. Portofolio efisien merupakan portofolio yang menghasilkan tingkat keuntungan tertentu dengan risiko terendah, atau risiko tertentu dengan tingkat keuntungan tertinggi (Achmad et al., 2015). Portofolio optimal merupakan portofolio yang dipilih atas banyak pilihan yang terdapat dalam portofolio efisien (Tandelilin, 2010).

Pembentukan portofolio saham perusahaan PT ABC dilakukan dengan portofolio optimal menggunakan pendekatan single index model. Pada model indeks tunggal, pergerakan saham diasumsikan memiliki korelasi dengan suatu indeks tertentu (Halim, 2015). Penyusunan portofolio optimal pada penelitian ini dilakukan dengan melihat tujuan serta profil risiko perusahaan. Portofolio juga disusun dengan mempertimbangkan adanya pandemi virus corona (Covid-19) yang terjadi di sepanjang tahun 2020 yang telah menimbulkan dampak negatif kepada ekonomi. Proses pemilihan emiten sebagai kelas aset akan dibatasi oleh ketentuan dan panduan investasi perusahaan.

Pemilihan emiten PT ABC didasarkan pada dua pertimbangan, yakni value stock dan growth stock. Pada value stock, saham-saham dipilih dengan mempertimbangkan aspek fundamental yang baik, likuiditas pasar yang tinggi, serta market capitalization yang tinggi. Sedangkan pada growth stock, pemilihan saham-saham didasarkan dengan mempertimbangkan aspek prospek bisnis emiten yang bagus dengan historical pertumbuhan yang meningkat secara berkesinambungan. Pemilihan saham-saham yang didasarkan pada value stock dilakukan untuk tujuan investasi jangka panjang perusahaan, sedangkan penggunaan growth stock digunakan dengan tujuan mendapatkan yield maksimal dengan mempertimbangkan momentum pasar yang tepat.

Oleh karena itu pada penelitian ini penyusunan portofolio optimal akan dilakukan pada kondisi pasar normal atau stabil, yang kemudian akan divalidasi untuk melihat performa portofolio pada saat pandemi atau saat ekonomi tidak stabil. Jika terindikasi performa portofolio terdampak buruk akibat pandemi Covid-19, maka akan dilakukan screening dengan melihat pergerakan harga aset perusahaan pada kurun waktu tertentu dan analisa pada sektor-sektor industri yang ada di pasar untuk mengidentifikasi sektor yang tidak terpengaruh oleh Covid-19, atau bahkan mampu mencetak pertumbuhan selama masa pandemi. Hal ini tentunya dapat menjadi pertimbangan penting dalam mitigasi risiko akibat portofolio aset yang terdampak selama masa pandemic Covid-19.

\section{METODE PENELITIAN}

Penelitian ini merupakan penelitian kuantitatif dan merupak jenis riset terapan dimana penyusunan strategi alokasi investasi dilakukan berdasarkan kondisi portofolio produk XYZ pada PT ABC dengan mempertimbangkan aspek ketentuan perundang-undangan berlaku yang mengikat perusahaan. Penelitian terapan merupakan penelitian yang dilakukan dengan tujuan untuk 
menyelesaikan masalah tertentu yang dihadapi oleh perusahaan (Sekaran \& Bougie, 2016).

Jenis penelitian yang dilakukan merupakan penelitian deskriptif kuantitatif. Data kuantitatif yang digunakan yakni data historis time series atas emiten-emiten yang termasuk ke dalam portofolio saham perusahaan. Data penelitian menggunakan data pergerakan saham harian yang mengalami perubahan harga dan ditransaksikan setiap hari (5 hari dalam seminggu), ditetapkan berdasarkan harga penutupan

Metode yang digunakan yakni studi dokumentasi dari laporan portofolio investasi PT ABC pada salah satu produk investasi PT ABC, website investing (investing.com), website Bursa Efek Indonesia (www.idx.co.id) serta website Bank Indonesia (www.bi.go.id) serta studi pustaka melalui panduan investasi perusahaan, panduan manajemen risiko perusahaan, serta naskah akademik seperti buku dan penelitian terdahulu.

\section{Metode Analisis Data Value at Risk}

1. Menghitung distribusi return

$$
R_{t}=\ln \left(\frac{R_{t}}{R_{t-1}}\right)
$$

Dimana:

$$
\begin{array}{ll}
\mathrm{R}_{\mathrm{t}} & : \text { Return aset periode ke } \mathrm{t} \\
\mathrm{P}_{\mathrm{t}} & : \text { Nilai/price } \text { aset periode ke } \mathrm{t} \\
\mathrm{P}_{\mathrm{t}-1} & : \text { Nilai/price } \text { aset periode ke } \mathrm{t}-1
\end{array}
$$

2. Menghitung volatilitas distribusi return

$$
\sigma=\sqrt{\frac{\sum_{i=1}^{n}\left(x_{i}-\mu\right)^{2}}{(n-1)}}
$$

Di mana:
$\sigma /(\mathrm{S}) \quad$ : Standar Deviasi
$\mathrm{x}_{\mathrm{i}} /\left(\mathrm{R}_{\mathrm{t}}\right)$ : Return variabel ke-i
$\mu /\left(\hat{\mathrm{R}}_{\mathrm{t}}\right) \quad$ : Mean
n : Jumlah variable

3. Menghitung VaR model Variance-Covariance

$$
V a R=V_{0} \alpha \sigma \sqrt{t}
$$

Dimana:

$$
\begin{array}{ll}
\mathrm{V}_{0} & \text { : Nilai eksposure / value dari aset } \\
\sigma & : \text { Volatilitas } \\
\alpha & \text { : Confidence level } \\
\mathrm{t} & \text { : Jangka waktu (time horizon) }
\end{array}
$$

Volatilitas sendiri merupakan fluktuasi atas return-return suatu sekuritas atau portofolio pada suatu periode waktu tertentu, sedangkan Confidence level mengacu pada ukuran kepercayaan atas level probabilitas terjadinya estimasi nilai $\mathrm{X}$ dalam suatu parameter.

\section{Metode Analisis Data Model Indeks Tunggal}

1. Beta dari portofolio $(\beta p)$ merupakan rata-rata tertimbang dari Beta masing-masing emiten

$$
\beta_{p}=\sum_{i=1}^{n} w_{i} \cdot \beta_{i}
$$

Dimana:

$$
\begin{array}{ll}
\text { Bp } & : \text { Beta portofolio } \\
\text { wi } & : \text { Proporsi saham ke-i } \\
\beta \mathrm{i} & : \text { Beta individual saham ke-i }
\end{array}
$$

2. Alpha dari portfolio ( $\alpha p)$ merupakan rata-rata tertimbang dari Alpha tiap-tiap emiten ( $\alpha \mathrm{i})$ :

$$
\alpha_{p}=\sum_{i=1}^{n} w_{i} \cdot \alpha_{i}
$$

Dimana:

$$
\begin{array}{ll}
\text { ap } & \text { : Alpha portofolio } \\
\text { wi } & \text { : Proporsi saham ke-i } \\
\text { ai } & : \text { Alpha individual saham ke-i }
\end{array}
$$

3. Return Ekspektasian dari portofolio atas ratarata tertimbang dari return ekspektasian individual saham

$$
E\left(R_{p}\right)=\alpha_{p}+\beta_{p} \cdot E\left(R_{m}\right)
$$

Di mana: 
Saputra, R.D. \& Alifiandipura, I. (2021). Rancangan Strategi Portofolio Optimal PT. ABC dengan Metode Single Index ...

$$
\begin{array}{ll}
\text { E(Rp) } & : \text { Ekspektasi Return Portofolio } \\
\text { ap } & : \text { Alpha Portofolio } \\
\beta p & : \text { Beta Portofolio } \\
\text { E(Rm) } & : \text { Ekspektasi Return Pasar }
\end{array}
$$

4. Menghitung Risiko Portofolio menggunakan varian

$$
\sigma_{p}{ }^{2}=\beta_{p}{ }^{2} \cdot \sigma_{M}{ }^{2}
$$

Dimana:

$\begin{array}{ll}\sigma \mathrm{p} & : \text { Varian portofolio } \\ \beta \mathrm{p} & : \text { Beta Portofolio } \\ \sigma \mathrm{M} & : \text { Varian pasar }\end{array}$

5. Excess Return to Beta mengukur kelebihan return relative terhadap suatu risiko yang tidak dapat didiversifikasikan denggan menggunakan

$$
\mathrm{ERB}_{i}=\frac{\mathrm{E}\left(\mathrm{R}_{\mathrm{i}}\right)-\mathrm{R}_{\mathrm{BR}}}{\beta_{\mathrm{i}}}
$$

Dimana:

ERBi : Excess Return to Beta

E(Ri) : Return ekspektasi sekuritas ke-i

RBR : Return Aktiva Bebas Risiko

$\beta$ i $\quad$ : Beta Sekuritas ke-i

6. Menhitung proporsi setiap saham

$$
w_{i}=\frac{Z_{i}}{\sum_{j=1}^{k} Z_{j}}
$$

Dimana:

$$
\begin{array}{ll}
\mathrm{W}_{\mathrm{i}} & : \text { Proporsi saham ke-i } \\
\mathrm{k} & : \text { Jumlah sekuritas di portofolio } \\
& \text { optimal }
\end{array}
$$

7. Menghitung nilai $\mathrm{Z}_{\mathrm{i}}$

$$
Z_{i}=\frac{\beta_{i}}{\sigma_{e i}{ }^{2}} E R B_{i} C^{*}
$$

Dimana:

$$
\begin{array}{ll}
\beta_{\mathrm{i}} & : \text { Beta sekuritas ke-i } \\
\sigma_{\mathrm{ei}}{ }^{2} & : \text { Varian dari kesalahan residu } \\
& \text { sekuritas ke-i }
\end{array}
$$
ERB $_{\mathrm{i}} \quad$ : Excess Return to Beta sekuritas ke-i
C* : Nilai cut-off point yang merupakan nilai Ci terbesar

\section{HASIL DAN PEMBAHASAN}

Relatif besarnya dana pensiun yang dikelola menjadikan perusahaan $\mathrm{ABC}$ sebagai kelompok yang diperhitungkan di industri keuangan. Dengan kewajiban memberikan jaminan dan keamanan sistem pensiun membuat perusahaan menjadi lembaga yang diawasi dengan ketat oleh regulator. PT ABC sebagai pengelola dana pensiun sendiri memiliki portofolio investasi yang terdiri dari beberapa jenis instrumen, salah satunya saham, di mana memiliki risiko dan volatilitas cukup tinggi dibandingkan instrumen lain seperti obligasi dan deposito, mengingat pergerakan harga aset dan fluktuasi pergerakan pasar modal yang terbilang tinggi dibandingkan instrument investasi lainnya. Oleh karenanya penerapan model VaR atas investasi yang dilakukan lembaga dana pensiun menjadi sangat penting dalam mengukur risiko perusahaan. Value at Risk (VaR) adalah suatu metode pengukuran risiko secara statistik yang digunakan untuk memperkirakan kerugian maksimum yang mungkin terjadi atas suatu portofolio pada tingkat kepercayaan (level of confidence) tertentu (Best, 1998).

Pendekatan VaR menggunakan 3 model berbeda telah peneliti lakukan pada penelitian sebelumnya. Penelitian tersebut dilakukan dalam rentang waktu distribusi satu tahun, untuk melihat model yang cocok digunakan pada portofolio investasi perusahaan. Penelitian tersebut menunjukkan bahwa model VaR menggunakan Variance-Covariance Method dinilai lebih baik digunakan daripada dua 
model lainnya yaitu Historical dan Monte-Carlo, di mana nilai VaR menggunakan metode VarianceCovariance menunjukkan hasil yang lebih akurat pada dua tingkat konfidensi berbeda dan menghasilkan exceed value atau error value yang lebih kecil dibandingkan dua model lainnya.

Pada penelitian tersebut juga terindentifikasi aset-aset yang memiliki risiko nilai VaR yang sangat besar, meskipun komposisi aset tersebut terbilang sangat kecil dibanding aset lain. Oleh karena itu pada tahap selanjutnya di penelitian ini, dipilihlah model VaR dengan menggunakan Variance-Covariance Method dan memperluas batasan rentang waktu penelitian menjadi 5 tahun dan monthly distribution, mengingat kebijakan investasi yang dilakukan perusahaan bersifat bulanan. Tujuan perhitungan $\mathrm{VaR}$ pada tahap ini ialah sebagai bahan pertimbangan dan evaluasi atas tingkat risiko pada komposisi aset pada portofolio yang dimiliki perusahaan.

Tabel 1. Current VaR portofolio (95\% CL)

\begin{tabular}{cccccc}
\hline No & \multirow{2}{*}{ Kode } & $\begin{array}{l}\text { Porto } \\
\text { Value }\end{array}$ & Exp Vol & VaR (Rp) & $\begin{array}{c}\text { VaR } \\
(\%)\end{array}$ \\
\hline 1 & \multirow{2}{*}{ AGRO } & $\begin{array}{l}\mathrm{Rp} \\
99,550\end{array}$ & $19.98 \%$ & $\begin{array}{l}\mathrm{Rp} \\
2,718\end{array}$ & $32.9 \%$ \\
\hline 2 & \multirow{2}{*}{ ANTM } & $\begin{array}{l}\mathrm{Rp} \\
69,350\end{array}$ & $13.58 \%$ & $\begin{array}{l}\mathrm{Rp} \\
5,490\end{array}$ & $22.3 \%$ \\
\hline 3 & BBRI & $\begin{array}{l}\mathrm{Rp} \\
5,149\end{array}$ & $7.13 \%$ & $\begin{array}{l}\mathrm{Rp} \\
604\end{array}$ & $11.7 \%$ \\
\hline 4 & BBYB & $\begin{array}{l}\mathrm{Rp} \\
178,000\end{array}$ & $36.88 \%$ & $\begin{array}{l}\mathrm{Rp} \\
107,971\end{array}$ & $60.7 \%$ \\
\hline 5 & BJBR & $\begin{array}{l}\mathrm{Rp} \\
884,894\end{array}$ & $14.51 \%$ & $\begin{array}{l}\mathrm{Rp} \\
211,155\end{array}$ & $23.9 \%$ \\
\hline 6 & BMRI & $\begin{array}{l}\mathrm{Rp} \\
4,990\end{array}$ & $5.79 \%$ & $\begin{array}{l}\mathrm{Rp} \\
475\end{array}$ & $9.5 \%$ \\
\hline 7 & BRIS & $\begin{array}{l}\mathrm{Rp} \\
14,062\end{array}$ & $8.95 \%$ & $\begin{array}{l}\mathrm{Rp} \\
2,070\end{array}$ & $14.7 \%$ \\
\hline 8 & FIRE & $\begin{array}{l}\mathrm{Rp} \\
736,796\end{array}$ & $19.76 \%$ & $\begin{array}{l}\mathrm{Rp} \\
239,476\end{array}$ & $32.5 \%$ \\
\hline 9 & GMFI & $\begin{array}{l}\mathrm{Rp} \\
135,000\end{array}$ & $11.12 \%$ & $\begin{array}{l}\mathrm{Rp} \\
24,682\end{array}$ & $18.3 \%$ \\
\hline 10 & IIKP & $\begin{array}{l}\mathrm{Rp} \\
301,176\end{array}$ & $25.74 \%$ & $\begin{array}{l}\mathrm{Rp} \\
127,490\end{array}$ & $42.3 \%$ \\
\hline 11 & INAF & $\begin{array}{l}\mathrm{Rp} \\
1,089,649\end{array}$ & $27.76 \%$ & $\begin{array}{l}\mathrm{Rp} \\
497,461\end{array}$ & $45.7 \%$ \\
\hline 12 & KAEF & $\begin{array}{l}\mathrm{Rp} \\
815,030\end{array}$ & $17.40 \%$ & $\begin{array}{l}\mathrm{Rp} \\
233,331\end{array}$ & $28.6 \%$ \\
\hline
\end{tabular}

\begin{tabular}{cccccc}
\hline No & Kode & $\begin{array}{l}\text { Porto } \\
\text { Value }\end{array}$ & Exp Vol & VaR (Rp) & $\begin{array}{l}\text { VaR } \\
(\%)\end{array}$ \\
\hline 13 & KRAS & $\begin{array}{l}\mathrm{Rp} \\
190,612\end{array}$ & $11.70 \%$ & $\begin{array}{l}\mathrm{Rp} \\
36,683\end{array}$ & $19.2 \%$ \\
\hline 14 & \multirow{2}{*}{ NIKL } & $\begin{array}{l}\mathrm{Rp} \\
423,314\end{array}$ & $31.51 \%$ & $\begin{array}{l}\mathrm{Rp} \\
219,419\end{array}$ & $51.8 \%$ \\
\hline 15 & PCAR & $\begin{array}{l}\mathrm{Rp} 350,54 \\
1\end{array}$ & $17.83 \%$ & $\begin{array}{l}\mathrm{Rp} \\
102,789\end{array}$ & $29.3 \%$ \\
\hline 16 & POLA & $\begin{array}{l}\mathrm{Rp} 380,00 \\
2\end{array}$ & $36.16 \%$ & $\begin{array}{l}\mathrm{Rp} \\
226,020\end{array}$ & $59.5 \%$ \\
\hline 17 & POOL & $\begin{array}{l}\mathrm{Rp} 249,96 \\
0\end{array}$ & $23.13 \%$ & $\begin{array}{l}\mathrm{Rp} \\
95,099\end{array}$ & $38.0 \%$ \\
\hline 18 & \multirow{2}{*}{ PPRO } & $\begin{array}{l}\mathrm{Rp} \\
952,290\end{array}$ & $15.50 \%$ & $\begin{array}{l}\mathrm{Rp} \\
242,739\end{array}$ & $25.5 \%$ \\
\hline 19 & SMBR & $\begin{array}{l}\mathrm{Rp} \\
816,604\end{array}$ & $16.46 \%$ & $\begin{array}{l}\mathrm{Rp} \\
221,097\end{array}$ & $27.1 \%$ \\
\hline 20 & \multirow{2}{*}{ SMRU } & $\begin{array}{l}\mathrm{Rp} \\
69,990\end{array}$ & $23.80 \%$ & $\begin{array}{l}\mathrm{Rp} \\
27,398\end{array}$ & $39.1 \%$ \\
\hline 21 & TRAM & $\begin{array}{l}\mathrm{Rp} \\
32,600\end{array}$ & $24.74 \%$ & $\begin{array}{l}\mathrm{Rp} \\
13,266\end{array}$ & $40.7 \%$ \\
\hline Portofolio & $\begin{array}{l}\mathrm{Rp} \\
7,799,559\end{array}$ & $9.09 \%$ & $\begin{array}{c}\mathrm{Rp} \\
1,165,736\end{array}$ & $14.9 \%$ \\
\hline
\end{tabular}

Sumber : Diolah penulis (2020)

Tabel di atas menunjukkan hasil perhitungan VaR pada confidence level 95\% menggunakan distribusi bulanan selama 5 tahun terakhir. VaR masing masing aset bervariasi dengan rata-rata sekitar 32\% dan VaR portofolio sebesar 14,9\%. Jika dilihat dari loss masing masing aset, pada dasarnya memang asetaset yang memiliki loss dengan jumlah besar merupakan aset yang memiliki komposisi cukup besar juga dalam portofolio, seperti INAF, SMBR, FIRE, KAEF dan BJBR. Meskipun begitu rata-rata VaR yang dimiliki aset-aset tersebut masih diantara $30-40 \%$.

Namun yang menarik adalah, jika diperhatikan terdapat aset-aset dengan proporsi kecil dalam portofolio namun memiliki loss yang cukup besar bahkan melebihi VaR dari aset-aset yang bahkan komposisinya dua kali lipat, di antara lain adalah BBYB, POLA, NIKL, IIKP. Misalnya BBYB dan POLA yang mencapai $60 \%$ VaR, menandakan volatilitas dan risiko aset ini sangat tinggi dan harus diperhatikan lebih lanjut. Hasil perhitungan ini menunjukkan hasil yang sama dengan dengan perhitungan yang peneliti 
Saputra, R.D. \& Alifiandipura, I. (2021). Rancangan Strategi Portofolio Optimal PT. ABC dengan Metode Single Index ...

lakukan sebelumnya dengan metode, rentang waktu dan distribusi yang lebih pendek pada perusahaan dan produk yang sama.

Model Single Index mengasumsikan pergerakan harga sekuritas berfluktuasi sesuai dengan indeks pasar. Pada penelitian ini dilakukan simulasi portofolio ke dalam beberapa kondisi sesuai dengan profil risiko untuk menentukan alokasi optimal demi mendapatkan return maksimal dengan tingkat risiko tertentu. Sama seperti analisis VAR yang dilakukan sebelumnya, data distribusi return yang digunakan untuk melakukan pengukuran adalah data distribusi bulanan return selama 5 tahun. Dari data tersebut dapat diukur nilai Coefficent Beta, Alfa, Residual Variance masing-masing sekuritas serta tingkat Variance dan Return Portofolio.

Tabel 2. Optimalisasi Portofolio

\begin{tabular}{ccccccc}
\hline No & Stocks & Current P & Max R & Min V & Min V BC \\
\hline 1 & AGRO & $1.28 \%$ & $9.34 \%$ & $1.69 \%$ & $0.42 \%$ & $0.06 \%$ \\
\hline 2 & ANTM & $0.89 \%$ & $0.06 \%$ & $1.16 \%$ & $5.00 \%$ & $8.00 \%$ \\
\hline 3 & BBRI & $0.07 \%$ & $0.06 \%$ & $0.99 \%$ & $5.00 \%$ & $8.00 \%$ \\
\hline 4 & BBYB & $2.28 \%$ & $10.00 \%$ & $7.59 \%$ & $8.79 \%$ & $10.00 \%$ \\
\hline 5 & BJBR & $11.35 \%$ & $0.06 \%$ & $0.96 \%$ & $0.06 \%$ & $0.06 \%$ \\
\hline 6 & BMRI & $0.06 \%$ & $0.06 \%$ & $1.04 \%$ & $5.00 \%$ & $8.00 \%$ \\
\hline 7 & BRIS & $0.18 \%$ & $0.06 \%$ & $0.98 \%$ & $5.00 \%$ & $8.00 \%$ \\
\hline 8 & FIRE & $9.45 \%$ & $10.00 \%$ & $10.00 \%$ & $8.66 \%$ & $5.87 \%$ \\
\hline 9 & GMFI & $1.73 \%$ & $0.06 \%$ & $1.49 \%$ & $0.06 \%$ & $0.06 \%$ \\
\hline 10 & IIKP & $3.86 \%$ & $0.06 \%$ & $0.71 \%$ & $0.06 \%$ & $0.06 \%$ \\
\hline 11 & INAF & $13.97 \%$ & $10.00 \%$ & $8.73 \%$ & $8.12 \%$ & $7.33 \%$ \\
\hline 12 & KAEF & $10.45 \%$ & $10.00 \%$ & $10.00 \%$ & $9.01 \%$ & $8.00 \%$ \\
\hline 13 & KRAS & $2.44 \%$ & $0.06 \%$ & $1.19 \%$ & $0.06 \%$ & $0.06 \%$ \\
\hline 14 & NIKL & $5.43 \%$ & $10.00 \%$ & $8.32 \%$ & $7.77 \%$ & $7.28 \%$ \\
\hline 15 & PCAR & $4.49 \%$ & $10.00 \%$ & $10.00 \%$ & $9.03 \%$ & $7.39 \%$ \\
\hline 16 & POLA & $4.87 \%$ & $0.06 \%$ & $2.63 \%$ & $0.92 \%$ & $0.06 \%$ \\
\hline 17 & POOL & $3.20 \%$ & $10.00 \%$ & $9.97 \%$ & $9.01 \%$ & $7.33 \%$ \\
\hline 18 & PPRO & $12.21 \%$ & $10.00 \%$ & $10.00 \%$ & $8.94 \%$ & $7.13 \%$ \\
\hline 19 & SMBR & $10.47 \%$ & $10.00 \%$ & $10.00 \%$ & $8.96 \%$ & $7.21 \%$ \\
\hline 20 & SMRU & $0.90 \%$ & $0.06 \%$ & $1.25 \%$ & $0.06 \%$ & $0.06 \%$ \\
\hline 21 & TRAM & $0.42 \%$ & $0.06 \%$ & $1.28 \%$ & $0.06 \%$ & $0.06 \%$ \\
\hline P Variance & $0.44 \%$ & $0.59 \%$ & $0.44 \%$ & $0.44 \%$ & $0.44 \%$ \\
\hline P Return & $2.68 \%$ & $5.35 \%$ & $4.27 \%$ & $4.27 \%$ & $3.76 \%$ \\
\hline Sumber : Diolah penulis 2020 & & &
\end{tabular}

Tabel di atas menunjukkan hasil optimalisasi portofolio menggunakan beberapa simulasi berbeda. Pemodelan SIM dilakukan menggunakan bantuan solver pada Microsoft Excel, untuk menghitung portofolio return dan variance di tingkat tertentu pada kondisi optimal. Pada current atau actual allocation bisa diketahui alokasi maksimal terdapat pada INAF (13.97\%) dan alokasi minimal di emiten BMRI (0.06\%), dengan 5-6 emiten utama dengan komposisi terbesar, dan menghasilkan portofolio variance sebesar $0.44 \%$ serta portofolio return sebesar $2.68 \%$.

Optimalisasi portofolio dilakukan dengan beberapa skenario, yang pertama dilakukan dengan mengoptimalkan return portofolio (Max R) dimana maksimal alokasi pada masing-masing aset adalah $10 \%$ sesuai dengan kebijakan investasi perusahaan, dan untuk minimal alokasi diambil dari existing portofolio sebesar $0.06 \%$. Dilakukan juga peaking untuk melihat sejauh mana proporsi bisa ditarik atau dikurangi dan sejauh mana bisa mempengaruhi return dan variance portofolio. Diketahui jika minimum alokasi dinaikkan lebih dari $0.07 \%$ maka akan menyebabkan penurunan pada portofolio return secara bertahap. Pada optimalisasi return ini diketahui current portofolio dengan komposisi tersebut bisa menghasilkan portofolio return sebesar 5.35\% dan portofolio variance sebesar $0.59 \%$.

Skenario selanjutnya ialah dengan menetapkan risiko atau variance portofolio di titik tertentu dan mengoptimalkan alokasi masing-masing aset sehingga bisa menghasilkan return yang lebih baik. Tingkat variance diambil dari existing portfolio variance sebesar $0.44 \%$, di mana dengan mempertahankan nilai variance tersebut didapatkan alokasi aset yang lebih optimal yang dapat menghasilkan portofolio return sebesar $4.27 \%$. Selain itu dengan mengunci tingkat variance portofolio pada $0.44 \%$ tentu saja akan mempengaruhi nilai Value at Risk pada masing masing aset 
setelah dioptimalisasi, seperti yang terlihat di tabel berikut:

Tabel 3. VaR Portofolio setelah Optimalisasi

\begin{tabular}{cccccc}
\hline \multirow{2}{*}{ No } & \multirow{2}{*}{ Stocks } & \multicolumn{2}{c}{ VaR Current P } & \multicolumn{2}{c}{ VaR Optimal P } \\
\cline { 3 - 6 } & & VaR TA & VaR TP & VaR TA & VaR TP \\
\hline 1 & AGRO & $32.87 \%$ & $0.42 \%$ & $14.95 \%$ & $0.25 \%$ \\
\hline 2 & ANTM & $22.34 \%$ & $0.20 \%$ & $14.95 \%$ & $0.17 \%$ \\
\hline 3 & BBRI & $11.72 \%$ & $0.01 \%$ & $14.95 \%$ & $0.15 \%$ \\
\hline 4 & BBYB & $60.66 \%$ & $1.38 \%$ & $14.95 \%$ & $1.13 \%$ \\
\hline 5 & BJBR & $23.86 \%$ & $2.71 \%$ & $14.95 \%$ & $0.14 \%$ \\
\hline 6 & BMRI & $9.53 \%$ & $0.01 \%$ & $14.95 \%$ & $0.16 \%$ \\
\hline 7 & BRIS & $14.72 \%$ & $0.03 \%$ & $14.95 \%$ & $0.15 \%$ \\
\hline 8 & FIRE & $32.50 \%$ & $3.07 \%$ & $14.95 \%$ & $1.49 \%$ \\
\hline 9 & GMFI & $18.28 \%$ & $0.32 \%$ & $14.95 \%$ & $0.22 \%$ \\
\hline 10 & IIKP & $42.33 \%$ & $1.63 \%$ & $14.95 \%$ & $0.11 \%$ \\
\hline 11 & INAF & $45.65 \%$ & $6.38 \%$ & $14.95 \%$ & $1.30 \%$ \\
\hline 12 & KAEF & $28.63 \%$ & $2.99 \%$ & $14.95 \%$ & $1.49 \%$ \\
\hline 13 & KRAS & $19.24 \%$ & $0.47 \%$ & $14.95 \%$ & $0.18 \%$ \\
\hline 14 & NIKL & $51.83 \%$ & $2.81 \%$ & $14.95 \%$ & $1.24 \%$ \\
\hline 15 & PCAR & $29.32 \%$ & $1.32 \%$ & $14.95 \%$ & $1.49 \%$ \\
\hline 16 & POLA & $59.48 \%$ & $2.90 \%$ & $14.95 \%$ & $0.39 \%$ \\
\hline 17 & POOL & $38.05 \%$ & $1.22 \%$ & $14.95 \%$ & $1.49 \%$ \\
\hline 18 & PPRO & $25.49 \%$ & $3.11 \%$ & $14.95 \%$ & $1.49 \%$ \\
\hline 19 & SMBR & $27.08 \%$ & $2.83 \%$ & $14.95 \%$ & $1.49 \%$ \\
\hline 20 & SMRU & $39.15 \%$ & $0.35 \%$ & $14.95 \%$ & $0.19 \%$ \\
\hline 21 & TRAM & $40.69 \%$ & $0.17 \%$ & $14.95 \%$ & $0.19 \%$ \\
\hline VaR Portofolio & $14.95 \%$ & \multicolumn{3}{c}{$14.95 \%$} \\
\hline Sum & & & & \\
\hline
\end{tabular}

Sumber : Diolah penulis

Tabel di atas menunjukkan perubahan nilai VaR sekuritas terhadap total asetnya akibat perubahan komposisi setelah dilakukan optimalisasi. Karena variance portofolio pada optimalisasi sebelumnya dikunci pada $0.44 \%$ maka VaR portofolio yang didapatkan juga akan tetap sama yaitu $14.95 \%$ seperti sebelum optimalisasi. Bedanya nilai VaR sekuritas terhadap total asetnya masing masing setelah optimalisasi tidak akan melebihi 14.95\%.

Skenario selanjutnya dengan mempertimbangkan faktor market cap pada masing masing aset yang ada di dalam portofolio tersebut, karena seperti yang terlihat dari existing portofolio, aset aset dengan market cap yang besar seperti BBRI, ANTM dan BMRI justru memiliki proporsi yang terbilang kecil di dalam portofolio. Seperti yang kita ketahui saham saham yang memiliki kapitalisasi besar diatas 10T ini biasanya merupakan saham-saham yang dikenal luas oleh masyarakat dan memiliki penghasilan yang stabil sehingga sangat direkomendasikan untuk investasi jangka panjang bagi investor yang memiliki profil risiko konservatif dan mengutamakan keuntungan dari deviden yang dibagikan secara rutin. Oleh karena itu dengan tetap mempertahankan variance portofolio pada $0.44 \%$, optimalisasi dilakukan dengan mengalokasikan setidaknya 25\%-40\% dari komposisi total portofolio pada aset-aset dengan market cap tertinggi yang ada di portofolio.

Setelah dilakukan optimalisasi diketahui bahwa dengan mengalokasikan $25 \%$ pada aset aset dengan kapitaliasi besar tersebut, ternyata dapat menghasilkan return yang sama dengan optimalisasi sebelumnya yaitu sebesar $4.27 \%$, namun turun menjadi $3.76 \%$ jika dialokasikan lebih dari 40\%. Hal ini membuktikan bahwa pengalokasian dalam jumlah besar pada aset aset dengan kapitalisasi besar tidak selalu dapat menghasilkan pengembalian yang efektif dan efisien.

Portofolio optimal ini kemudian juga akan diuji ketahanannya pada masa krisis atau pandemi yang terjadi pada tahun 2020 untuk melihat dan membandingkan kondisi existing portofolio dan optimal portofolio tersebut.

Pandemi Covid-19 memberikan banyak dampak bagi perekonomian negara, termasuk dalam pasar modal. Pada tahap ini peneliti merasa perlu untuk melihat kembali kemampuan portofolio investasi perusahaan dalam menghadapi fluktuasi pasar modal selama masa pandemik. Analisa portofolio optimal yang dilakukan sebelumnya menggunakan asumsi ekonomi normal, di mana distribusi data yang diambil yaitu selama 5 tahun kebelakang, dimulai dari 
Saputra, R.D. \& Alifiandipura, I. (2021). Rancangan Strategi Portofolio Optimal PT. ABC dengan Metode Single Index ...

tahun 2014. Oleh karena itu untuk menguji kinerja portofolio optimal yang telah dibentuk sebelumnya, peneliti mengambil data distribusi return emiten-emiten yang ada pada portofolio selama masa pandemi sampai dengan penelitian ini dibuat, yaitu satu tahun penuh 2020.

Tabel 4. Portofolio optimal (SIM) masa pandemik No Stocks Current P Max R Min V Min V BC \begin{tabular}{lllllll}
\hline 1 & AGRO & $1.28 \%$ & $9.34 \%$ & $1.69 \%$ & $0.42 \%$ & $0.06 \%$ \\
\hline
\end{tabular} \begin{tabular}{lllllll}
\hline 2 & ANTM & $0.89 \%$ & $0.06 \%$ & $1.16 \%$ & $5.00 \%$ & $8.00 \%$ \\
\hline
\end{tabular} \begin{tabular}{llllllll}
\hline 3 & BBRI & $0.07 \%$ & $0.06 \%$ & $0.99 \%$ & $5.00 \%$ & $8.00 \%$ \\
\hline
\end{tabular} \begin{tabular}{lllllll}
\hline 4 & BBYB & $2.28 \%$ & $10.00 \%$ & $7.59 \%$ & $8.79 \%$ & $10.00 \%$ \\
\hline
\end{tabular} \begin{tabular}{lllllll}
\hline 5 & BJBR & $11.35 \%$ & $0.06 \%$ & $0.96 \%$ & $0.06 \%$ & $0.06 \%$ \\
\hline
\end{tabular} \begin{tabular}{llllllll}
\hline 6 & BMRI & $0.06 \%$ & $0.06 \%$ & $1.04 \%$ & $5.00 \%$ & $8.00 \%$ \\
\hline
\end{tabular} \begin{tabular}{lllllll}
\hline 7 & BRIS & $0.18 \%$ & $0.06 \%$ & $0.98 \%$ & $5.00 \%$ & $8.00 \%$ \\
\hline
\end{tabular} \begin{tabular}{lllllll}
\hline 8 & FIRE & $9.45 \%$ & $10.00 \%$ & $10.00 \%$ & $8.66 \%$ & $5.87 \%$ \\
\hline
\end{tabular} \begin{tabular}{ccccccc}
\hline 9 & GMFI & $1.73 \%$ & $0.06 \%$ & $1.49 \%$ & $0.06 \%$ & $0.06 \%$ \\
\hline
\end{tabular} \begin{tabular}{lllllll}
\hline 10 & IIKP & $3.86 \%$ & $0.06 \%$ & $0.71 \%$ & $0.06 \%$ & $0.06 \%$ \\
\hline
\end{tabular} \begin{tabular}{lllllll}
\hline 11 & INAF & $13.97 \%$ & $10.00 \%$ & $8.73 \%$ & $8.12 \%$ & $7.33 \%$ \\
\hline
\end{tabular} \begin{tabular}{lllllll}
112 & KAEF & $10.45 \%$ & $10.00 \%$ & $10.00 \%$ & $9.01 \%$ & $8.00 \%$ \\
\hline
\end{tabular} \begin{tabular}{lllllll}
\hline 13 & KRAS & $2.44 \%$ & $0.06 \%$ & $1.19 \%$ & $0.06 \%$ & $0.06 \%$ \\
\hline 14 & & &
\end{tabular} \begin{tabular}{lllllll}
13 & NIKL & $5.43 \%$ & $10.00 \%$ & $8.32 \%$ & $7.77 \%$ & $7.28 \%$ \\
\hline
\end{tabular} \begin{tabular}{lllllll}
15 & PCAR & $4.49 \%$ & $10.00 \%$ & $10.00 \%$ & $9.03 \%$ & $7.39 \%$ \\
\hline
\end{tabular} \begin{tabular}{lllllll}
\hline 16 & POLA & $4.87 \%$ & $0.06 \%$ & $2.63 \%$ & $0.92 \%$ & $0.06 \%$ \\
\hline
\end{tabular} \begin{tabular}{llllllll}
17 & POOL & $3.20 \%$ & $10.00 \%$ & $9.97 \%$ & $9.01 \%$ & $7.33 \%$ \\
\hline
\end{tabular} \begin{tabular}{llllllll}
\hline 18 & PPRO & $12.21 \%$ & $10.00 \%$ & $10.00 \%$ & $8.94 \%$ & $7.13 \%$ \\
\hline
\end{tabular} \begin{tabular}{lllllll}
19 & SMBR & $10.47 \%$ & $10.00 \%$ & $10.00 \%$ & $8.96 \%$ & $7.21 \%$ \\
\hline
\end{tabular} \begin{tabular}{lllllll}
\hline 20 & SMRU & $0.90 \%$ & $0.06 \%$ & $1.25 \%$ & $0.06 \%$ & $0.06 \%$ \\
\hline
\end{tabular}

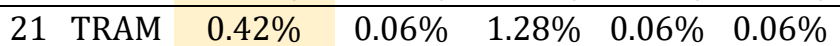
\begin{tabular}{llllll}
\hline P Variance & $2.08 \%$ & $1.97 \%$ & $1.64 \%$ & $1.58 \%$ & $1.53 \%$ \\
\hline
\end{tabular} \begin{tabular}{llllll}
\hline P Return & $4.65 \%$ & $6.28 \%$ & $4.35 \%$ & $4.91 \%$ & $5.26 \%$ \\
\hline
\end{tabular} Sumber: Diolah Penulis (2020)

Selain melihat kinerja current portofolio perusahaan pada masa pandemik, peneliti juga mengevaluasi kinerja portofolio optimal yang sebelumnya telah dibentuk. Tabel di atas adalah hasil analisis SIM portofolio optimal selama masa pandemi. Jika dibandingkan dengan data hasil analisis current portofolio selama masa pandemi, dapat dilihat dengan jelas bahwa portofolio optimal yang telah dibentuk sebelumnya ini memberikan output yang jauh lebih baik.

Portofolio optimal dengan menggunakan skenario pertama selama masa pendemi mengalami peningkatan portofolio return menjadi 6.28\% diikuti dengan kenaikan portofolio variance, yakni sebesar
1.97\%. Meskipun terbilang tinggi, hal ini masih jauh lebih baik dibandingkan dengan kondisi variance portofolio sebelum dilakukan optimalisasi yaitu sebesar $2.08 \%$

Perbandingan hasil optimalisasi pada portofolio di atas dapat dilihat pada tabel berikut ini:

Tabel 5. Perbandingan Portofolio Optimal masa Pandemi

\begin{tabular}{ccc}
\hline & Kondisi Normal & Masa Pandemi \\
\hline Current & P.Variance: $0.44 \%$ & P.Variance: $2.08 \%$ \\
Portofolio & P. Return: $2.68 \%$ & P. Return: $4.65 \%$ \\
\hline Optimal & P.Variance: $0.59 \%$ & P.Variance: $1.97 \%$ \\
Portofolio (Max & P. Return: $5.35 \%$ & P. Return: $6.28 \%$ \\
R) & & \\
\hline Optimal & P.Variance: $0.44 \%$ & P.Variance: $1.64 \%$ \\
Portofolio (Min & P. Return: $4.27 \%$ & P. Return: $4.35 \%$ \\
V) & & \\
\hline Optimal & P.Variance: $0.44 \%$ & P.Variance: $1.58 \%$ \\
Portofolio (Min V & P. Return: $4.27 \%$ & P. Return: $4.91 \%$ \\
BC) 25\% & & \\
\hline Optimal & P.Variance: $0.44 \%$ & P.Variance: $1.53 \%$ \\
Portofolio (Min V & P. Return: 3.76\% & P. Return: $5.26 \%$ \\
BC) 40\% & & \\
\hline Sumber: Diolah Penulis & \\
\hline
\end{tabular}

Tabel $5 \mathrm{di}$ atas menunjukkan hasil perbandingan dari beberapa optimalisasi yang dilakukan meng gunakan pendekatan yang berbeda. Skenario yang digunakan di antaranya, dengan memaksimalkan return, meminimalisir varians, mengunci varians pada level tertentu dan menambah indikator kapitalisasi pasar pada portofolio dengan komposisi $25 \%$ dan $40 \%$. Selain itu pengujian dilakukan juga pada dua situasi ekonomi berbeda yaitu kondisi normal dan kondisi pada masa pandemi.

Oleh karena itu dapat disimpulkan meskipun mengalami peningkatan signifikan pada portofolio return selama masa pandemi, risiko akibat volatilitas aset pada portofolio juga naik cukup tinggi, dan mengingat fokus perusahaan terhadap portofolio XYZ ini menggunakan risk-based approach, bisa dikatakan kinerja portofolio terbilang baik selama masa pandemi, 
dibandingkan dengan saat portofolio masih belum $\mathrm{d}$ optimalisasi.

Kondisi perekonomian yang lesu, gelombang phk yang tidak terelakan, hingga banyaknya perusahaan yang mengalami kerugian dan menutup bisnisnya membuat masyarakat sangat selektif dalam membelanjakan uangnya. Daya beli masyarakat melemah yang juga diikuti dengan deflasi memberikan sentimen negatif bagi pasar modal Indonesia. Namun ditengah banyaknya perusahaan yang mengalami kerugian, terdapat beberapa sektor ekonomi yang tidak terpengaruh atau memiliki dampak minimum selama pandemik yang tercermin dari beberapa emiten di pasar modal yang dapat bertahan dan bahkan mengalami pertumbuhan.

Saham-saham yang dapat bertahan dari krisis tentu perlu memiliki fundamental perusahaan yang kuat dan kinerja keuangan yang baik, di mana sahamsaham tersebut dapat tercermin dalam indeks LQ-45 di Bursa Efek Indonesia. Alternatif alokasi aset yang disusun peneliti merupakan komposisi saham-saham yang konsisten berada di indeks LQ-45 sejak tahun 2016 hingga tahun 2020. Berdasarkan sortir yang telah dilakukan, terdapat 29 emiten yang secara berturut-turut masuk ke dalam indeks LQ-45 selama 5 tahun terakhir yang dianggap merepresentasikan emiten-emiten dengan kinerja keuangan dan fundamental perusahaan terbaik.

Tabel 6. Alternatif alokasi aset I

\begin{tabular}{ccccc}
\hline No & Stocks & $\begin{array}{c}\text { Beta- } \\
\text { Coeff }\end{array}$ & Alpha-Coeff & Res Variance \\
\hline 1 & ADRO & 1.13159 & 0.01319 & 0.01045 \\
\hline 2 & AKRA & 1.92013 & -0.00430 & 0.00537 \\
\hline 3 & ANTM & 2.80436 & 0.05866 & 0.02345 \\
\hline 4 & ASII & 1.45509 & -0.00664 & 0.00644 \\
\hline 5 & BBCA & 0.87732 & 0.01282 & 0.00144 \\
\hline 6 & BBNI & 2.00184 & -0.00446 & 0.00566 \\
\hline 7 & BBRI & 1.38863 & 0.01009 & 0.00337 \\
\hline 8 & BBTN & 2.35138 & 0.00425 & 0.02523 \\
\hline 9 & BMRI & 1.53092 & -0.00030 & 0.00412 \\
\hline 10 & BSDE & 1.75273 & 0.00638 & 0.00534 \\
\hline
\end{tabular}

\begin{tabular}{ccccc}
\hline 11 & GGRM & 0.93967 & -0.02544 & 0.00492 \\
\hline 12 & HMSP & 1.02733 & -0.03247 & 0.00634 \\
\hline 13 & ICBP & 0.15238 & -0.00125 & 0.00514 \\
\hline 14 & INCO & 1.79190 & 0.02741 & 0.00845 \\
\hline 15 & INDF & 0.43821 & -0.00040 & 0.00625 \\
\hline 16 & INTP & 1.13704 & -0.00596 & 0.00499 \\
\hline 17 & JSMR & 1.87051 & 0.01471 & 0.01001 \\
\hline 18 & KLBF & 0.58338 & 0.00148 & 0.00482 \\
\hline 19 & MNCN & 1.82212 & 0.03488 & 0.01956 \\
\hline 20 & PGAS & 2.83499 & 0.00514 & 0.00523 \\
\hline 21 & PTBA & 0.77765 & -0.01280 & 0.00844 \\
\hline 22 & PTPP & 3.57968 & 0.02668 & 0.00806 \\
\hline 23 & SCMA & 2.03974 & 0.01959 & 0.01080 \\
\hline 24 & SMGR & 1.58734 & 0.01007 & 0.00655 \\
\hline 25 & SRIL & 1.60717 & -0.00575 & 0.00747 \\
\hline 26 & TLKM & 0.86033 & -0.00279 & 0.00326 \\
\hline 27 & UNTR & 0.69691 & 0.00334 & 0.00882 \\
\hline 28 & UNVR & 0.21438 & -0.00676 & 0.00435 \\
\hline 29 & WIKA & 2.64923 & 0.02532 & 0.00779 \\
\hline
\end{tabular}

Tabel 6 di atas menunjukkan salah satu hasil dari beberapa langkah pengujian SIM pada analisis alternatif aset portofolio baru, diluar existing portofolio perusahaan sebelumnya. Langkah pengujian yang dilakukan sama seperti sebelumnya, dengan 4 pendekatan pada dua kondisi ekonomi berbeda. Tujuannya untuk menguji ketahanan aset alternatif yang disarankan terhadap aset-aset pada existing portofolio perusahaan.

Tabel 7 Exsisting Alternatif alokasi aset I

\begin{tabular}{ccccc}
\hline No & Max R & Min V & Max R BC & $\begin{array}{c}\text { Min V } \\
\text { Bcap }\end{array}$ \\
\hline 1 & Optimal & Not & Not & Not \\
\hline 2 & Not & Not & Not & Not \\
\hline 3 & Optimal & Not & Optimal & Not \\
\hline 4 & Not & Not & Not & Not \\
\hline 5 & Not & Optimal & Optimal & Optimal \\
\hline 6 & Not & Not & Not & Not \\
\hline 7 & Not & Not & Optimal & Optimal \\
\hline 8 & Not & Not & Not & Not \\
\hline 9 & Not & Not & Optimal & Optimal \\
\hline 10 & Not & Not & Not & Not \\
\hline 11 & Not & Not & Not & Not \\
\hline 12 & Not & Not & Not & Not \\
\hline 13 & Not & Optimal & Not & Optimal \\
\hline 14 & Optimal & Not & Optimal & Not \\
\hline 15 & Not & Optimal & Not & Optimal \\
\hline 16 & Not & Not & Not & Not \\
\hline 17 & Optimal & Not & Not & Not \\
\hline 18 & Not & Optimal & Not & Optimal \\
\hline 19 & Optimal & Not & Optimal & Not \\
\hline & & & &
\end{tabular}


Saputra, R.D. \& Alifiandipura, I. (2021). Rancangan Strategi Portofolio Optimal PT. ABC dengan Metode Single Index ...

\begin{tabular}{ccccc}
\hline 20 & Not & Not & Not & Not \\
\hline 21 & Not & Optimal & Not & Optimal \\
\hline 22 & Optimal & Not & Optimal & Not \\
\hline 23 & Optimal & Not & Optimal & Not \\
\hline 24 & Not & Not & Not & Not \\
\hline 25 & Not & Not & Not & Not \\
\hline 26 & Not & Optimal & Optimal & Optimal \\
\hline 27 & Not & Optimal & Not & Optimal \\
\hline 28 & Not & Optimal & Optimal & Optimal \\
\hline 29 & Optimal & Not & Optimal & Not \\
\hline Sumber : Diolah Penulis $(2020)$ & &
\end{tabular}

Tabel di atas menujukkan perbandingan hasil optimalisasi 29 aset pada masing masing scenario berbeda. Hasilnya menunjukkan ada beberapa aset yang memang lebih optimal dibanding aset lainnya dalam beberapa kondisi berbeda, untuk kemudian dapat dijadikan sebagai alternatif alokasi aset baru, selain existing portofolio yang telah dioptimalisasi. Aset aset yang kemudian mampu bertahan di semua atau sebagian besar skenario kemudian dapat disimpulkan sebagai aset yang dapat dijadikan sebagai rekomendasi tujuan investasi selanjutnya. Oleh karena itu berdasarkan hasil pengujian tersebut didapatkan beberapa aset yang layak dijadikan sebagai tujuan investasi selanjutnya, diantaranya BBCA, ICBP, INDF, KLBF, TLKM dan UNVR. Semua saham di atas merupakan saham dengan kapitalisasi pasar yang besar dan memiliki tingkat risiko yang terbilang rendah serta merupakan perusahan yang stabil di pasar modal Indonesia. Selain itu berdasarkan hasil analisis diatas, saham saham ini juga memiliki daya tahan dan performa yang baik pada masa krisis.

\section{SIMPULAN}

Hasil olah data menggunakan single index model menghasilkan return serta risiko yang lebih baik dibandingkan dengan komposisi portofolio investasi saham sebelum nya. Hal ini dapat dilihat dari nilai return yang lebih tinggi dan risiko yang lebih rendah yang dihasilkan. Pada alternatif portofolio yang didasarkan pada sahamsaham yang konsisten berada pada indeks LQ45 selama 5 tahun berturut-turut juga menghasilkan nilai return yang lebih baik yang sejalan dengan panduan dan tujuan investasi perusaahaan.

\section{DAFTAR PUSTAKA}

Adiningrum, T. R., Hidayat, R. R., \& Sulasmiyati, S. (2016). Penggunaan Metode Single Index Model Dalam Menentukan Portofolio Optimal Tahun 2012-2015 (Studi pada Saham-Saham yang Terdaftar dalam Indeks IDX30 Di Bursa Efek Indonesia Periode Februari 2012 - Agustus 2015). Jurnal Administrasi Bisnis (JAB), 38(2).

Djohanputro, Bramantyo. (2008). Manajemen Risiko Korporat. Jakarta: PPM.

Eko, U. (2010). Analisis dan Penilaian Kinerja Portofolio Optimal Saham-Saham LQ-45. Bisnis \& Birokrasi Journal. 15(3)

Elton, E. J., Gruber, M. J., Brown, S. J., \& Goetzmann, W. N. (2014). Modern Portfolio Theory and Investment Analysis (9th ed., p. 1). New Jersey: John Wiley \& Sons.

Halim, A. (2015). Analisis Investasi dan Aplikasinya: Dalam Aset Keuangan dan Aset Riil. Jakarta: Salemba Empat.

Hartono, J. (2017). Teori Portofolio dan Analisis Investasi (11th ed.). Yogyakarta: BPFE.

Intanie Dewi, V. (2013). Asset Allocation: Diversification dan Rebalancing Sebagai Bagian dari Proses Perencanaan Keuangan (Suatu Kajian Pustaka). Bina Ekonomi Majalah Ilmiah Fakultas Ekonomi Unpar. 17(1).

Jayati, N., Ragil Handayani, S., \& Z.A, Z. (2017). Analisis Metode Single Index Model Dalam Pembentukan Portofolio Optimal Untuk Menurunkan Risiko Investasi (Studi Pada Perusahaan Yang Terdaftar Dalam Indeks Idx30 Periode Agustus 2013-Juli 2016). Jurnal Administrasi Bisnis (JAB). 49(1).

Jorion, P. (2002). Value at Risk: The New Benchmark for Managing Financial Risk (2nd ed.). New York: McGraw-Hill Professional Publishing.

Kupiec, P. (1995). Techniques for Verifying the Accuracy of Risk Management Models. Journal of Derivatives. 3.

Malikah A, Askandar N.S, dan Fadilah R. (2018). Penghitungan Value at Risk (Var) Portofolio Optimum Saham Perusahaan Berbasis Syariah Dengan Pendekatan Exponentially Weighted Moving Average (Ewma). E-JRA Vol. 07 No. 10 Agustus. Universitas Islam Malang

Nanda Oktaviani, B., \& Wijayanto, A. (2015). Aplikasi Single Index Model Dalam Pembentukan 
Portofolio Optimal Saham LQ45 Dan Jakarta Islamic Index. Management Analysis Journal. 4(1).

Noor Achmad, D., Sahala Marpaung, B., \& Febriyanti, D. (2015). Analisis Pemilihan Saham Dalam Pembentukan Portofolio Efisien Pada Saham Yang Tergabung Dalam LQ 45. Jurnal Ilmiah Manajemen Kesatuan. 3(3).

Penza, P., \& Bansal, V. K. (2001). Measuring Market Risk with Value at Risk. New York: John Wiley \& Sons, Inc.

Purbowati, Ari dan Maruddani, Di Asih I. (2009). Pengukuran Value at Risk Pada Aset Tunggal dan Portofolio dengan Simulasi Monte Carlo. Media Statistika. 2(2).

Purnamasari, Nur Asmita. (2017). Backtesting untuk Value at Risk pada Data Return Saham Bank Syariah menggunakan Quantile Regression. Thesis, Institut Teknologi Sepuluh November.

Ratna Adiningrum, T., Rustam Hidayat, R., \& Sulasmiyati, S. (2016). Penggunaan Metode Single Index Model Dalam Menentukan Portofolio Optimal Tahun 2012-2015 (Studi pada Saham-Saham yang Terdaftar dalam Indeks IDX30 Di Bursai Efeki Indonesia Periode Februari 2012 - Agustus 2015). Jurnal Administrasi Bisnis (JAB), 38(2).
Reilly, Frank K., Brown, Keith C., (2006), Investment Analysis and Portfolio Management (8th Edition). Canada: Thomson South-Western.

Sekaran, U., \& Bougie, R. (2016). Research Methods for Business: A Skill Building Approach (7th ed.). Chichester: John Wiley \& Sons.

Suprihatin, Ika \& Budiyanto. (2014). Analisis Portofolio Saham Menggunakan Metode Markowitz pada Perusahaan Retail di Bursa Efek Indonesia. Jurnal Ilmu dan Riset Manajemen Sekolah Tinggi Ilmu Ekonomi Indonesia (STIESIA). 3(11).

Tandelilin, E. (2010). Portofolio dan Investasi: Teori dan Aplikasi. Yogyakarta: Kanisius.

Trinarningsih, W... (2012). Optimal portfolio with single index model (case study in Main Board and Development Board Indonesian Stock Exchange in a period of January 2007December 2009) (Unpublished master's thesis). Sebelas Maret University. Solo.

Wicaksono, Bayu H, Rugisyono A, dan Wilandari Y. (2014). Perbandingan Metode Variance Covariance Dan Historical Simulation Untuk Mengukur Risiko Investasi Reksa Dana. Jurnal Gaussian, Vol. 03, No. 04: 585-594. Universitas Diponegoro. 